\title{
PERTUMBUHAN AKAR KEDELAI PADA CEKAMAN KEKERINGAN
}

\section{(The Growth of Soybean Root on Drought Stress)}

\section{Pienyani Rosawanti}

\author{
Dosen Program Studi Agroteknologi Fakultas Pertanian dan Kehutanan \\ Universitas Muhammadiyah Palangkaraya \\ e-mail : pienyani@yahoo.com
}

\begin{abstract}
Drought stress caused the changes in rooting system of soybean. The purpose of this experiment was to study the change of vegetative growth of root on some genotypes soybean on drought stress. This experiment was conducted in the Cikabayan greenhouse IPB using ten genotypes of soybean (Ratai, Seulawah, Slamet, Tanggamus, Wilis, GC 22-10, PG 57-1, SC 21-5, SC 39-1, SP 30-4) and PEG (0\%, 20\%). The drought stress was applied only at a vegetative phase.

The result showed that drought stress with PEG simulation significant effect on root length, branch roots number and root dry weight.
\end{abstract}

Key words: genotype, PEG, root, vegetative phase

\begin{abstract}
Abstrak
Cekaman kekeringan dapat menyebabkan perubahan sistem perakaran tanaman kedelai. Tujuan penelitian ini adalah mempelajari sistem perakaran beberapa genotipe kedelai pada kondisi kekeringan pada fase vegetatif. Penelitian dilaksanakan di rumah kaca Cikabayan-IPB menggunakan sepuluh genotipe kedelai (Ratai, Seulawah, Slamet, Tanggamus, Wilis, GC 22-10, PG 57-1, SC 21-5, SC 39-1, SP 30-4) dan PEG $(0 \%, 20 \%)$. Cekaman kekeringan hanya diberikan pada fase vegetatif.

Hasil penelitian menunjukkan bahwa cekaman kekeringan dengan simulasi PEG berpengaruh terhadap panjang akar, jumlah cabang akar dan bobot kering akar.
\end{abstract}

Kata kunci: fase vegetatif, genotipe, PEG, akar

\section{PENDAHULUAN}

Ketersediaan air yang rendah menyebabkan terjadinya cekaman kekeringan dan dapat mengganggu pertumbuhan dan perkembangan tanaman kedelai. Cekaman kekeringan pada tanaman disebabkan karena kurangnya suplai air di daerah perakaran atau permintaan air yang berlebihan oleh daun karena laju evapotanspirasi melebihi laju absorbsi air oleh akar tanaman, walaupun air tanah dalam keadaan cukup (Levitt, 1980).
Cekaman kekeringan merupakan salah satu kondisi lingkungan yang dapat mempengaruhi pertumbuhan dan produktivitas tanaman. Kekeringan dapat menyebabkan perubahan anatomi, morfologi, fisiologis, biokimia dan molekuler pada tanaman. Kemampuan tanaman untuk beradaptasi terhadap cekaman kekeringan tergantung pada intensitas dan periode cekaman, fase pertumbuhan dan genotype tanaman (Kalefetoglu dan Ekmekci, 2005). Respon tanaman terhadap cekaman kekeringan berbeda- 
beda tergantung pada lama, intensitas cekaman, spesies tanaman dan tahap pertumbuhan tanaman (Kusvuran, 2012).

Tanaman kedelai yang mengalami kekeringan pada fase vegetatif mengalami penurunan pertumbuhan dan perkembangan yang sangat besar (Aboyami, 2008), seperti dengan adanya penurunan tinggi tanaman, jumlah nodus, panjang akar, bobot kering akar dan tajuk (Riduan, 2005). Ini merupakan strategi konservatif untuk mempertahankan penggunaan energi, dimana tanaman akan mengembangkan respon yang lebih komplek untuk perbaikan toleransi terhadap periode kekurangan air lebih lanjut (Kron et al., 2008).

Saat terjadi cekaman kekeringan, tanaman lebih banyak mengembangkan sistem perakaran (Lynch, 2007). Sel-sel akar mengalami perubahan antara lain dengan meningkatkan atau mengurangi jumlah maupun ukuran dalam menghadapi cekaman kekeringan. Respon fisiologi dan morfologi tanaman kedelai yang tahan terhadap cekaman kekeringan adalah dengan adanya peningkatan bobot kering akar dan panjang akar, peningkatan kandungan prolin dan penurunan potensial osmotik daun (Hamim et al., 1996; Ashri K, 2006; Lobato et al., 2008), serta peningkatan berat kering akar pada kacang tanah (Puangbut et al., 2009; Songsri et al., 2009). Selain itu juga terjadi peningkatan jumlah rambut akar yang akan meningkatkan kemampuan tanaman untuk menyerap air (Vasellati et al., 2001).
Simulasi lingkungan yang mengalami cekaman kekeringan dapat dilakukan dengan perlakuan pemberian PEG (poly-ethylene glycol). Penggunaan PEG yang dilarutkan dalam air dapat digunakan untuk meniru besarnya potensial air (Michel dan Kaufmann, 1973). Terjadi pada penelitian lain, aplikasi PEG menyebabkan terjadinya penyusutan tinggi tanaman, berkurangnya jumlah daun, peningkatan intensitas kerusakan daun, peningkatan panjang akar dan rasio bobot kering akar-tajuk (Sunaryo, 2002), menghambat pertumbuhan sel kalus kedelai (Husni et al., 2006) dan perkecambahan serta pertumbuhan tanaman kedelai (Widoretno et al., 2002). Pada tanaman lain, aplikasi PEG dapat menghambat pemanjangan daun pada jagung (Chazen dan Neumann, 1994), menghambat perkembangan fase vegetatif pada kacang tanah (Susilawati, 2003), menurunnya kadar air relatif daun serta meningkatnya akumulasi prolin (Kocheva dan Georgiev, 2003), millet (Radhouane, 2007), kacang karas/kekara (Bhardwaj dan Yadav, 2012; Murthy, 2012) dan padi (Afa et al., 2013).

Tujuan penelitian ini adalah mempelajari sistem perakaran beberapa genotipe kedelai pada kondisi kekeringan pada fase vegetatif.

\section{METODOLOGI}

Bahan yang digunakan adalah 10 genotipe kedelai yaitu: Ratai, Seulawah, Slamet, Tanggamus, Wilis, GC 22-10, PG 57-1, SC 21-5, SC 39-1, SP 30-4, PEG 6000, aquadest, pupuk urea, pupuk SP 18 dan pupuk 
$\mathrm{KCl}$, pasir dan tanah. Sedangkan alat yang digunakan adalah polibag, meteran, timbangan analitik, gelas ukur dan oven. Penelitian ini dilakukan di Rumah Kaca Cikabayan IPB dengan menggunakan Rancangan Acak Kelompok Lengkap (RAKL) yang disusun secara faktorial dengan 2 faktor. Faktor pertama adalah 10 genotipe kedelai yaitu Ratai, Seulawah, Slamet, Tanggamus, Wilis, GC 2210, PG 57-1, SC 21-5, SC 39-1, SP 30-4. Faktor kedua adalah konsentrasi PEG yang terdiri dari $0 \%$ dan 20\% yang masing-masing setara dengan potensial osmotik $0 \mathrm{Mpa}$ dan -0,67 Mpa (Mexal, 1975). Perlakuan diulang sebanyak tiga kali.

Penelitian ini menggunakan polibag berdiameter $20 \mathrm{~cm}$ yang diisi campuran tanah dan pasir dengan perbandingan $2: 1$ sebanyak $8 \mathrm{~kg}$. Setiap polibag ditanam 2 benih kedelai dan pada umur 3 minggu dilakukan penjarangan dengan meninggalkan satu tanaman per polibag yang pertumbuhannya paling baik. Sebelum penanaman dilakukan pemupukan dasar dengan menggunakan Urea, SP-18 dan $\mathrm{KCl}$. Pemupukan kedua dilakukan setelah tanaman berumur 3 minggu. Penyiangan dilakukan secara berkala dengan mencabut tanaman pengganggu yang tumbuh di dalam polibag. Pemeliharaan dilakukan terus menerus hingga tanaman dipanen.

\section{Pemberian PerlakuanCekaman Kekeringan}

Larutan PEG dibuat dengan melarutkan kristal PEG 6000 sesuai konsentrasi perlakuan dengan air sampai volume mencapai 1 liter. Larutan PEG diberikan pada tanaman sejak tanaman memiliki daun trifoliat yang telah berkembang sempurna sebanyak $20 \mathrm{ml}$ setiap 2 hari sekali sampai tanaman mulai memasuki fase reproduktif ( \pm umur 30 hari).

\section{Pengamatan}

Pengamatan dilakukan pada umur 31 HST/setelah pemberian perlakuan cekaman kekeringan, terhadap :

1. Panjang akar $(\mathrm{cm})$. Diukur dari pangkal akar sampai ujung akar dengan cara meluruskan akar yang bergulung.

2. Jumlah cabang akar. Menghitung semua jumlah akar yang tumbuh pada akar primer.

3. Bobot kering akar (g). Akar dipisahkan dari tajuknya kemudian dicuci sampai bersih dan dimasukkan ke dalam oven dengan suhu $70^{\circ} \mathrm{C}$ selama 48 jam sampai beratnya konstan, lalu ditimbang dengan timbangan analitik.

\section{Analisis Data}

Analisis data dilakukan dengan analisis ragam, apabila berpengaruh nyata akan dilakukan analisis lanjutan dengan uji jarak berganda atau DMRT (Duncan Multiple Range Test) pada taraf $5 \%$.

\section{HASIL DAN PEMBAHASAN}

Hasil analisis sidik ragam menunjukkan bahwa genotipe berpengaruh nyata terhadap bobot kering akar dan jumlah akar lateral. Perlakuan PEG berpengaruh terhadap peubah panjang akar, bobot kering dan jumlah cabang akar. Interaksi terdapat pada peubah bobot kering akar dan jumlah akar lateral (Tabel 1). 
Tabel 1. Rekapitulasi sidik ragam karakter 10 genotipe kedelai terhadap perlakuan PEG di rumah kaca

\begin{tabular}{lccc}
\hline \multicolumn{1}{c}{ Karakter } & Genotipe $(\mathbf{G})$ & PEG $(\mathbf{P})$ & Interaksi $(\mathbf{G x P})$ \\
\hline Panjang akar primer $(\mathrm{cm})$ & tn & $*$ & tn \\
Bobot kering akar $(\mathrm{g})$ & $* *$ & $*$ & $*$ \\
Jumlah cabang akar & $*$ & $*$ & $*$ \\
\hline
\end{tabular}

Keterangan: th : tidak berbeda nyata pada taraf $5 \%$,

** : berbeda nyata pada taraf $5 \%$, dan

* : berbeda nyata pada taraf $1 \%$.

Tanaman kedelai yang mengalami kekeringan pada fase vegetatif mengalami penurunan pertumbuhan dan perkembangan yang sangat besar (Riduan 2004; Aboyami 2008). Hal ini merupakan strategi konservatif untuk mempertahankan penggunaan energi, dimana tanaman akan mengembangkan respon yang lebih komplek untuk perbaikan toleransi terhadap periode kekurangan air lebih lanjut (Kron et al., 2008).

\section{Panjang Akar Primer}

Cekaman kekeringan menghambat proses pembelahan dan pembesaran sel pada akar, akibatnya pertumbuhan akar menjadi terhambat. PEG 0\% mempunyai respon panjang akar primer tertinggi $(14.160 \mathrm{~cm})$ dan berbeda nyata dengan perlakuan PEG 20\%, penurunan panjang akar sebesar 35.19\% (Tabel 2). Pada tanaman kacang hijau (Ranawake et al. 2011), cekaman kekeringan pada awal fase vegetatif menyebabkan terjadinya penurunan panjang akar primer.

\section{Jumlah Cabang Akar}

Pada saat terjadi cekaman kekeringan sistem perakaran akan mengalami perubahan dan pertambahan struktur yaitu bertambahnya jumlah akar untuk mendukung fungsi akar dalam penyerapan air. Pada padi terjadi peningkatan jumlah akar yang akan meningkatkan kemampuan tanaman untuk menyerap air (Henry et al., 2012).

Cekaman kekeringan menyebabkan penurunan jumlah akar lateral pada GC 22-10, Ratai dan PG 57-1 (50\%, 35.14\% dan 16\%). Pada varietas kacang tunggak terjadi penurunan jumlah akar lateral pada kondisi kekeringan dengan simulasi PEG (Badiane et al., 2004). Wilis mengalami peningkatan jumlah akar lateral terbesar yaitu sebesar 154\% (Tabel 3). Hal ini mengindikasikan bahwa Wilis mengalami perubahan respon terhadap cekaman kekeringan dengan memperbanyak cabang akar. Perubahan fisiologi tersebut dikarenakan akar memperluas volume untuk memperluas daerah penyerapan air. 
Tabel 2. Pengaruh simulasi PEG terhadap peubah panjang akar, cabang akar dan bobot kering akar

\begin{tabular}{crrrrrr}
\hline \multirow{2}{*}{ PEG (\%) } & \multicolumn{7}{c}{ Peubah } \\
\cline { 2 - 7 } & Panjang Akar $(\mathbf{c m})$ & Jumlah Cabang Akar & Bobot Kering Akar (g) \\
\hline 0 & 14,160 & a & 11,200 & b & 0.13 & a \\
20 & 9,177 & b & 12,767 & a & 0.03 & b \\
\hline Penurunan (\%) & 35,19 & 13,99 & $(+)$ & 75.58 & \\
\hline
\end{tabular}

Keterangan : Angka-angka yang diikuti oleh huruf yang sama pada kolom yang sama, tidak berbeda nyata pada taraf uji $5 \%$ (DMRT)

Tabel 3. Interaksi genotipe dan konsentrasi PEG terhadap peubah jumlah akar lateral kedelai

\begin{tabular}{|c|c|c|c|}
\hline \multirow{2}{*}{ Genotipe } & \multicolumn{2}{|c|}{ PEG (\%) } & \multirow{2}{*}{$\begin{array}{c}\text { Penurunan Relatif } \\
\text { Terhadap Kontrol }(\%)\end{array}$} \\
\hline & $\mathbf{0}$ & 20 & \\
\hline Ratai & $12.33 \mathrm{bcA}$ & $8.00 \mathrm{cdA}$ & 35.14 \\
\hline Seulawah & $10.33 \mathrm{cA}$ & $12.00 \mathrm{bA}$ & $16.13+$ \\
\hline Slamet & $12.00 \mathrm{bcA}$ & $15.00 \mathrm{abA}$ & $25.00+$ \\
\hline Tanggamus & $9.00 \mathrm{~cd} A$ & $13.00 \mathrm{bcB}$ & $44.44+$ \\
\hline Wilis & $7.33 \mathrm{dA}$ & $18.67 \mathrm{aB}$ & $154.55+$ \\
\hline GC $22-10$ & $17.33 \mathrm{aA}$ & $8.67 \mathrm{cdB}$ & 50.00 \\
\hline PG 57-1 & $8.33 \mathrm{dA}$ & $7.00 \mathrm{dA}$ & 16.00 \\
\hline SC $21-5$ & $10.33 \mathrm{cA}$ & $16.67 \mathrm{abA}$ & $61.29+$ \\
\hline SC 39-1 & $12.67 \mathrm{bA}$ & $14.33 \mathrm{abA}$ & $13.16+$ \\
\hline SP 30-4 & $12.33 \mathrm{bcA}$ & $14.33 \mathrm{abA}$ & $16.22+$ \\
\hline
\end{tabular}

Keterangan : Angka yang diikuti huruf kecil pada kolom yang sama dan huruf besar pada baris yang sama menunjukkan hasil yang tidak berbeda nyata berdasarkan DMRT pada $\alpha=5 \%$. ; tanda $(+)$ menunjukkan adanya peningkatan

\section{Bobot Kering Akar}

Cekaman kekeringan pada percobaan ini menyebabkan penurunan bobot kering akar sebesar $75.58 \%$ (Tabel 1). Bobot kering akar dipengaruhi secara nyata oleh genotipe dan PEG. Saat cekaman kekeringan, penurunan bobot kering akar terjadi pada semua genotipe dan terbesar pada SC 21-5 yang mengalami penurunan $89.03 \%$, dan terendah pada PG 57-1 dan Wilis masing-masing sebesar $51.07 \%$ dan $52.82 \%$ (Tabel 4). Penurunan bobot kering akar diduga terkait dengan penurunan laju fotosintesis selama cekaman kekeringan. Penelitian Hanum et al., (2007), Wilis mengalami penurunan bobot kering akar terendah pada perlakuan cekaman kekeringan. Hasil pada penelitian lain menunjukkan bahwa penurunan bobot kering akar pada kedelai yang mengalami cekaman kekeringan (Ashri, 2000; Sunaryo, 2003) dan kacang hijau (Ranawake et al., 2011). 
Tabel 4. Interaksi genotipe dan konsentrasi PEG terhadap peubah bobot kering akar (g) kedelai

\begin{tabular}{|c|c|c|c|}
\hline \multirow{2}{*}{ Genotipe } & \multicolumn{2}{|c|}{ PEG (\%) } & \multirow{2}{*}{$\begin{array}{c}\text { Penurunan Relatif } \\
\text { Terhadap Kontrol }(\%)\end{array}$} \\
\hline & $\mathbf{0}$ & 20 & \\
\hline Ratai & $0.13 \mathrm{bA}$ & $0.03 \mathrm{bB}$ & 75.78 \\
\hline Seulawah & $0.12 \mathrm{bcA}$ & $0.03 \mathrm{cdB}$ & 78.45 \\
\hline Slamet & $0.08 \mathrm{cA}$ & $0.02 \mathrm{~dB}$ & 76.99 \\
\hline Tanggamus & $0.14 \mathrm{bA}$ & $0.03 \mathrm{cdB}$ & 81.42 \\
\hline Wilis & $0.09 \mathrm{cA}$ & $0.04 \mathrm{bB}$ & 52.82 \\
\hline GC 22-10 & $0.12 \mathrm{bcA}$ & $0.03 \mathrm{cdB}$ & 78.46 \\
\hline PG 57-1 & $0.08 \mathrm{cA}$ & $0.04 \mathrm{bcB}$ & 51.07 \\
\hline SC $21-5$ & $0.17 \mathrm{aA}$ & $0.02 \mathrm{~dB}$ & 89.03 \\
\hline SC $39-1$ & 0.14 & $0.03 \mathrm{bcB}$ & 75.13 \\
\hline SP $30-4$ & $0.13 \mathrm{bcA}$ & $0.06 \mathrm{aB}$ & 57.85 \\
\hline
\end{tabular}

Keterangan : Angka yang diikuti huruf kecil pada kolom yang sama dan huruf besar pada baris yang sama menunjukkan hasil yang tidak berbeda nyata berdasarkan DMRT pada $\alpha=5 \%$

\section{SIMPULAN}

Cekaman kekeringan dengan simulasi PEG pada awal fase vegetatif menyebabkan pengaruh negatif terhadap pertumbuhan dan perkembangan akar tanaman. Cekaman kekeringan dengan simulasi PEG berpengaruh terhadap panjang akar, jumlah cabang akar dan bobot kering akar. Mekanisme toleransi kedelai pada kondisi kekeringan adalah dengan meningkatkan jumlah cabang akar.

\section{DAFTAR PUSTAKA}

Aboyami YA. 2008. Comparative growth and grain yield responses of early and late soybean maturity group to induced soil moisture stress at different growth stages.World J Agric Sci. 4(1):71-78.

Afa LO,Purwoko BS, Junaedi A, Haridjaja O, Dewi IS. 2013. Deteksi dini toleransi padi hibrida terhadap kekeringan menggunakan PEG 6000. J Agron Indonesia. 41(1): 9-15.
Ashri K. 2006. Akumulasi enzim antioksidan dan prolin pada beberapa varietas kedelai toleran dan peka cekaman kekeringan [tesis]. Bogor (ID): Institut Pertanian Bogor.

BadianeFA, Diouf D, Sane1 D, Diouf O, Goudiaby V, Diallo N. 2004. Screening cowpea [Vigna unguiculata (L.) Walp.]varieties by inducing water deficit and RAPD analyses. Afr $J$ Biotech. 3(3):174-178.

Bhardwaj J, Yadav SK. 2012. Comparative study on biochemical parameters and antioksidant enzymes in a drought tolerant and a sensitive variety of horsegram (Macrotyloma uniflorum) under drought stress. AmJ Plant Physiol. 7(1):17-29.

Chazen O, Neumann PM. 1994. Hydraulic signals from the roots and rapid cell-wall hardening in growing maize (Zeamays L.) leaves are primary responses to polyethylene glycol-lnduced water deficits. Plant Physiol. 104:1385-1392. 
Hamim, Sopandie D, Jusuf M. 1996. Beberapa karakteristik morfologi dan fisiologi kedelai toleran dan peka terhadap cekaman kekeringan. Hayati. 3(1):30-34.

Hanum C. Mugnisjah WQ, Yahya S. Sopandy D. Idris K. Sahar A. 2007. Pertumbuhan akar kedelai pada cekaman aluminium, kekeringan dan cekaman ganda aluminium dan kekeringan. Agritrop. 26(1):13-18.

Henry A, Cal AJ,Batoto TC,Torres RO,Serraj R. 2012. Root attributes affecting water uptake of rice (Oryza sativa) under drought. J Exp Bot. 63:4751-4763.

Husni AM, Kosmiatin M, Mariska I. 2006. Peningkatan toleransi kedelai Sindoro terhadap kekeringan melalui seleksi in vitro. Bul Agron. 34(1):25-31.

Kalefetoglu T. Ekmekci Y. 2005. The effects of drought on plants and tolerant mechanisms. J Sci. 18(4):723-740.

Kocheva K, Georgiev G. 2003. Evaluation of the reaction of two contrasting barley (Hordeum vulgarel L.) cultivars in response to osmotic stress with PEG 6000. BulgJ Plant Physiol Special Issue:290-294.

Kron AP, Souza GM, Ribeiro RV. 2008. Water deficiency at different developmental stagesof Glycine max can improve drought tolerance. Bragantia Campinas. 1(67):43-49.

Kusvuran, S. 2012. Influence of drought stress on growth, ion accumulation and antioxidative enzymes in okragenotypes. International JAgricBiol.14: 401-406.

Levitt J. 1980. Responses of Plants to Environmental Stresses. Ed ke-2. New York (US): Academic Pr.

Lynch JP, Brown KM. 2012. New roots for agriculture: exploiting the root phenome. Phil Trans R Soc B. 367: 1598-1604.
Lobatto AKS, Filho BGS, Costa RCL, Neto CFO, Meirelles ACS, Cruz FJR, Alves GAR, Neves HKB, Pita JD, Lopes MJS, Freitas JMN, Monteiro BS, Ramos RF. 2008. Physiological and biochemical changes in soybean (Glycine max) plants under progressive water deficit during the vegetatif phase. Agric J. 3(5):327333.

Murthy SM, Devaraj VR, Anitha P, Tejavathi DH. 2012. Studies on the activities of antioxidant enzymes under induced drought stress in in vivo and in vitro plants of Macrotyloma uniflorum (Lam.) Verdc. RRST. 4(2): 34-37.

Mexal J, Fisher JT, Osteryoung J, Reid CPP. 1975. Oxygen availability in polyethylene glycol solution and its implications in plant-water relation. Plant Physiol. 55:20-24.

Puangbut D, Jogloy S, Vorasot N, Akkasaeng C, Kesmala T, Rachaputi RCN, Wright GC, Patanothai A. 2009. Association of root dry weight and transpiration efficiency of peanut genotypes under early season drought. Agric Water Manage. 96:1460-1466.

Radhouane, L. 2007. Response of Tunisian autochthonous pearl millet (Pennisetum glaucum (L.) R. Br.) to drought stress induced by polyethylene glycol (PEG) 6000. Afr J Biotech. 6(9):1102-1105.

Ranawake AL, Amarasingha UGS, Rodrigo WDRJ, Rodrigo UTD, Dahanayaka N. 2011. Effect of water stress on growth and yield of mung bean (Vigna radiate L). Trop Agric Res Extension. 14(4): 7679

Riduan A, Aswidinnoor H, Koswara J, Sudarsono. 2005. Toleransi sejumlah kultivar kacang tanah terhadap cekaman kekeringan. Hayati. 12(1): 28-34.

Songsri P, Jogloy S, Holbrook CC, Kesmala T, Vorasot N, Akkasaeng C, Patanothai A. 2009. Association of root, specific leaf area and SPAD chlorophyll meter 
reading to water use efficiency of peanut under different available soil water. Agric Water Manage. 96:790-798.

Sunaryo W. 2002. Regenerasi dan evaluasi variasi somaklonal kedelai (Glycine max (L.) Merrill) hasil kultur jaringan serta seleksi terhadap cekaman kekeringan menggunakan simulasi Poly Ethylene Glycol (PEG) [tesis]. Bogor (ID): Institut Pertanian Bogor.

Susilawati PN. 2003. Respon 16 kultivar kacang tanah unggul nasional (Arachis hypogaea L.) terhadap kondisi stress kekeringan akibat perlakuan penyiraman PEG 6000 dan evaluasi daya regenerasi embrio somatiknya secara in vitro [tesis]. Bogor: Institut Pertanian Bogor.

Vasellati V, Oesterhel M, Medan D, Loreti J. 2001. Effects of flooding and drought on the anatomy of Paspalum dilatatum. Ann Bot. 88:355-360.

Widoretno W, Guhardja E, Ilyas S, Sudarsono. 2002. Efektivitas polyethylene glycol untuk mengevaluasi tanggapan grnotipe kedelai terhadap cekaman kekeringan pada fase perkecambahan. Hayati. 9(2):33-36. 